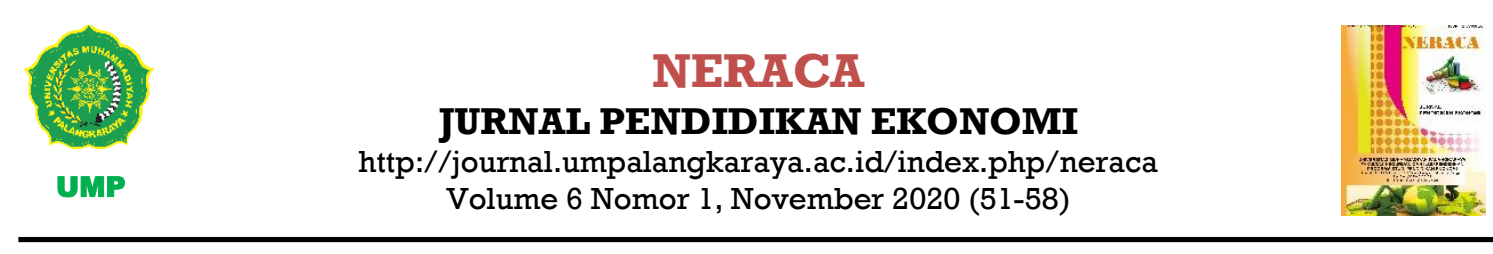

\title{
UPAYA MENINGKATKAN HASIL BELAJAR IPS MELALUI MODEL STUDENT TEAM ACHIEVEMENT DIVISION PADA SIMP MUHAMIMADIYAH PALANGKARAYA
}

Efforts To Improve Social Studies Learning Outcomes Using The Student Team Achievement Learning Division Model At SMP Muhammadiyah Palangkaraya 'Muhammad Asrori dan ${ }^{2}$ Diana Lupy

'Universitas Muhammadiyah Palangkaraya, Palangka Raya, Kalimantan Tengah, Indonesia

${ }^{2}$ Universitas Muhammadiyah Palangkaraya, Palangka Raya, Kalimantan Tengah, Indonesia

\section{ARTIKEL INFO}

Diterima

September 2020

Dipublikasi

November 2020

\section{ABSTRAK}

Penelitian ini bertujuan untuk: (I) mendeskripsikan aktivitas belajar peserta didik pada saat proses pembelajaran IImu Pengetahuan Sosial (IPS) dengan menggunakan model pembelajaran Student Team Achievement Division, (2) meningkatkan hasil belajar Ilmu Pengetahuan Sosial (IPS) dengan menggunakan model pembelajaran Student Team Achievement Division pada peserta didik kelas VII-C di SMP Muhammadiyah Palangkaraya. Subjek pada penelitian ini adalah seluruh peserta didik kelas VII-C SMP Muhammadiyah Palangka Raya yang berjumlah 25 orang peserta didik. Jenis penelitian yang digunakan adalah Penelitian Tindakan Kelas (PTK) dengan model pembelajaran Student Team Achievement Division. Hasil penelitian ini menunjukan bahwa: (I) peserta didik lebih aktif pada saat pembelajaran IPS dengan menggunakan model pembelajaran Student Team Achievement Division. Siklus I, skor rata-rata 3,2 dengan kriteria baik kemudian pada siklus II meningkat dengan skor rata-rata 3,8 dengan kriteria baik, (2) ada peningkatan hasil belajar IPS peserta didik setelah menggunakan model pembelajaran Student Team Achievement Division. Terlihat dari hasil belajar peserta didik pada tes awal memperoleh nilai rata-rata 34 (dibawah nilai KKM $\geq 70$ ) dengan ketuntasan klasikal $4 \%$ dengan kriteria tidak tercapai. . Pada Siklus I hasil belajar peserta didik memperoleh nilai rata-rata 50 dengan ketuntasan klasikal $20 \%$ dengan kriteria tidak tercapai. Pada Siklus II terdapat peningkatan hasil belajar peserta didik memperoleh nilai rata-rata 84 dengan ketuntasan klasikal 92\% dengan kriteria tercapai

Kata kunci: Hasil Belajar IPS, Model Pembelajaran Student Team Achievement Division.

\section{ABSTRACT}

This study aims to: (I) describe the learning activities of students during the learning process of Social Sciences (IPS) using the Student Team Achievement Division learning model, (2) improve the learning outcomes of Social Sciences (IPS) using the Student Team learning model Achievement Division in VII-C class students at SMP Muhammadiyah Palangkaraya. The subjects in this study were all students of class VII-C of Muhammadiyah Middle School in Palangka Raya, which numbered 25 students. The type of research used is Classroom Action Research (CAR) with the Student Team Achievement Division learning model. The results of this study indicate that: (I) students are more active during social studies learning using the Student Team Achievement Division learning model. Cycle I, the average score of 3.2 with good criteria then in the second cycle increased with an average score of 3.8 with good criteria, (2) there was an increase in social studies learning outcomes of students after using the Student Team Achievement Division learning model. It can be seen from the learning outcomes of students in the initial test that they obtained an average score of 34 (below the KKM value $\geq 70$ ) with $4 \%$ classical completeness with the criteria not reached. . In the first cycle the learning outcomes of students obtain an average value of 50 with classical completeness of $20 \%$ with criteria not reached. In Cycle II there was an increase in learning outcomes students gained an average value of 84 with $92 \%$ classical completeness with the criteria achieved..

Keywords: Social Studies Learning Outcomes, Student Team Achievement Division Learning Model. 


\section{PENDAHULUAN}

Hasil belajar merupakan hasil dari proses belajar mengajar yang mana seorang guru bisa melihat apakah pembelajaran bisa diterima dan dimengerti oleh peserta didiknya dan untuk itu guru dituntut untuk memiliki keterampilan dalam proses belajar mengajar agar pembelajaran berjalan dengan menyenangkan, bisa diterima, dan tujuan pendidikan bisa tercapai. Oleh sebab itu, setiap guru memiliki cara-cara atau metode yang berbeda-beda dalam pembelajaran namun dengan tujuan yang sama, yaitu hasil belajar peserta didik mencapai nilai KKM yang mana sebagai nilai yang menjadi ukuran tercapainya suatu pembelajaran. Salah satunya adalah model pembelajaran kooperatif.

Pada pembelajaran dengan model kooperatif peserta didik dilatih untuk bekerja sama dalam satu tim mengatasi suatu masalah, menyelesaikan sebuah tugas untuk mencapai tujuan bersama. Model pembelajaran kooperatif berperan bagi peserta didik dalam mengembangkan interaksi sosial dan keterampilan komunikasi.

Terdapat beberapa model pembelajaran yang ditawarkan dan perlu dikembangkan di sekolah. Salah satunya adalah model pembelajaran kooperatif tipe Student Team Achievement Division (STAD) yang dikembangkan oleh Slavin dan temantemannya di Universitas John Hopkins, dan merupakan model pembelajaran yang palingsederhana Ibrahim (Majid, 2013:184). Dalam pembelajaran ini peserta didik diberikan kesempatan untuk melakukan kolaborasi dan elaborasi dengan teman sebaya melalui kerja sama dalam diskusi kelompok untuk memecahkan suatu masalah menurut Arindawati dan Hosnan (2014:246).

Untuk mengatasi permasalahan ini diperlukan adanya usaha-usaha tertentu untuk meningkatkan hasil belajar peserta didik agar tujuan dari pembelajaran dapat tercapai. Pemeiti memilih model pembelajaran Student
Team Achievement Division (STAD) yang dapat dijadikan upaya untuk meningkatkan hasil belajar peserta didik agar mereka menjadi lebih aktif dalam pembelajaran. Model pembelajaran kooperatif tipe Student Team Achievement Division (STAD) bertujuan agar proses belajar tidak lagi berpusat pada guru, melainkan berpusat pada peserta didik. Sehingga dengan model pembelajaran kooperatif tipe Student Team Achievement Division (STAD) dapat menumbuhkan minat belajar dan meningkatkan hasil belajar peserta didik khususnya pada mata pelajaran IPS.

Berdasarkan latar belakang diatas, peneliti tertarik untuk melakukan penelitian dengan judul "Upaya Meningkatkan Hasil Belajar IPS Melalui Model Student Team Achievement Division Pada Peserta Didik Kelas VII-C SMP Muhammadiyah Palangkaraya ".

Istilah belajar sebenarnya telah lama dikenal, setiap orang mempunyai pendapat masing-masing tentang pengertian belajar. Sebagian orang beranggapan bahwa belajar adalah proses melihat, mengamati, dan memahami sesuatu dan adapun sebagian orang beranggapan bahwa belajar adalah menuntut ilmu atau mencari ilmu.

Ada beberapa pendapat para ahli tentang pengertian belajar, menurut Suprahatiningrum (20I4:20I5) yaitu :

Belajar merupakan suatu proses usaha yang dilakukan individu secara sadar untuk memperoleh perubahan tingkah laku tertentu, baik yang diamati secara langsung sebagai pengalaman (latihan) dalm interaksinya dengan lingkungan. Dapat dikatakan juga bahwa belajar sebagai suatu aktivitas mental atau psikis yang berlangsung dalam interaksi aktif dengan lingkungan dan menghasilkan perubahan dalam pengetahuan pemahaman, keterampilan serta nilai-nilai dan sikap.

Perkembangan model pembelajaran dari waktu ke waktu terus meng alami perubahan. Model-model pembelajaran tradisional kini mulai diringgalkan dan diganti 
dengan model yang lebih modern. Model pembelajaran merupakan suatu pendekatan yang digunakan dalam kegiatan pembelajaran. Dibawah ini beberapa definisi para ahli tentang model pembelajaran, yaitu:

Aunurrahman (2010:146), berpendapat bahwa:

Model pembelajaran merupakan kerangka konseptual yang melukiskan prosedur yang sistematis dalam mengorganisasikan pengalaman belajar untuk mencapai tujuan belajar tertentu, dan berfungsi sebagai pedoman bagi pada perancang pembelajaran dan para guru untuk merencanakan dan melaksanakan aktivitas pembelajaran.

Model pembelajaran tipe Student Team Achievement Division (STAD) dikembangkan oleh Slavin dan teman-temannya di Universitas John Hopkins, dan merupakan model pembelajaran yang paling sederhana Ibrahim (Majid, 2013:184). Dalam pembelajaran ini peserta didik diberikan kesempatan untuk melakukan kolaborasi dan elaborasi dengan teman sebaya melalui kerja sama dalam diskusi kelompok untuk memecahkan suatu masalah menurut Arindawati dan Hosnan (2014:246).

Dalam pembelajaran STAD, siswa masuk kedalam kelompok-kelompok kecil yang beranggotakan 4-5 peserta didik yang memiliki perbedaan kemempuan, jenis kelamin, suku, dan budaya. Guru menyampaikan materi pelajaran, kemudian peserta didik akan mengerjakan kuis mengenai materi yang telah dipelajari secara individu dan tidak boleh saling membenatu. Menurut Slavin (2010:143) Student Team Achievement Division (STAD) terdiri atas 5 komponen utama yaitu presentasi kelas, tim, kuis, skor kemajuan individual, dan rekognisitim.

Dari pendapat para ahli diatas dapat disimpulkan model pembelajaran tipe Student Team Achievement Division (STAD) adalah model pembelajaran yang memberikan kesempatan pada peserta didik untuk melakukan kolaborasi dan elaborasi dengan teman sebaya melalui kerja sama dalam diskusi kelompok untuk memecahkan suatu masalah.

Menurut Hosnan (2014:247) langkahlangkah model pembelajaran Student Team Achievement Division (STAD) sebagai berikut:

I. Membentuk kelompok yang anggotanya 4 orang secara heterogen.

2. Guru menyajikan materi pelajaran.

3. Guru memberi tugas kepada kelompok untuk dikerjakan oleh anggota-anggota kelompok. Anggota kelompok yang tahu menjelaskan pada anggota lainnya sampai semua anggota dalam kelompok itu mengerti.

4. Guru memberikan kuis pertanyaan kepada seluruh peserta didik. Pada saat menjawab kuis, tidak boleh saling membantu.

5. Pembahasan kuis dan member evaluasi.

6. Kesimpulan.

\section{METODE PENELITIAN}

Dalam penelitian ini menggunakan metode pendekatan penelitian kelas (PTK). Menurut Diplan dan Andi Setiawan (2018:120) Penelitian Tindakan Kelas adalah penelitian yang dilakukan oleh guru dengan maksud untuk melihat kemempuan diri dan memperbaiki kualitas proses pembelajaran kelas, sehingga hasil belajar siswa dapat ditingkatkan, aktifitas belajar peserta didik menjadi semakin baik dan aktif.

Menurut Kunandar (20I2:45) Penelitian Tindakan Kelas (PTK) adalah "penelitian tindakan yang dilakukan dengan tujuan memperbaiki mutu praktik pembelajaran di kelas". PTK juga menjembatani kesenjangan antar teori dan praktik pendidikan. Hal ini terjadi karena kegiatan dilaksanakan sendiri dikelas, dengan melibatkan peserta didik melalui tindakan yang direncanakan, 
dilaksanakan dan dievaluasi. Dengan demikian. Dengan demikian, diperoleh umpan balik yang sistematis mengenai apa yang selama ini dilakukan dalam kegiatan belajar mengajar. Penelitian ini bertujuan untuk memecahkan atau menjawab permasalahan yang dihadapi pada situasi sekarang.

Adapun jenis penelitian yang digunakan adalah "penelitian tindakan kelas, dimana peneliti terlibat langsung dalam penelitian sejak awal sampai dengan hasil penelitian berupa laporan" Akhmad Sudrajat (2008). Dalam penelitian ini peneliti bertindak sebagai peneliti dan pengajar yang akan mengajarkan peserta didik dengan berpedoman pada perencanaan pembelajaran. Dengan demikian, sejak perencanaan penelitian peneliti senantiasa terlibat, selanjutnya peneliti memantau, mencatat, dan mengumpulkan data, lalu menganalisa data serta berakhir dengan melaporkan hasil penelitian.

Menurut Diplan dan Andi, (2018:65-66) menyatakan bahwa:

"Subjek penelitian adalah sekumpulan sasaran dari penelitian yang dilaksanakan, subjek tindakan kelas yaitu sejumlah orang baik laki-laki ataupun perempuan, subjek penelitian terkait dengan peserta didik sedangkan objek penelitian adalah tindakan yang didalamnya berisi model, strategi, teknik,ataupun media atau disebut objek proses, dan masalah pembelajaran yang ada merupakan bentuk objek produk".

Subjek penelitian pada penelitian tindakan kelas ini adalah seluruh peserta didik kelas VII-C SMP Muhammadiyah Palangka Raya.

Objek penelitian dalam penelitian ini adalah menggunakan penerapan model pembelajaran Student Team Achievement Division, alasan peneliti memilih objek tersebut karena sangat sesuai dengan karakteristik peserta didik serta ruang lingkup lingkungan sekolah sehingga dapat mengaktifkan aktivitas dan meningkatkan hasil belajar peserta didik.
Rancangan penelitian yang peneliti pilih dalam penelitian ini yakni model Penelitian Tindakan Kelas (PTK) dari Kemmis dan Mc. Taggart, yang dimana menurut Diplan dan Andi (2018:32) menyatakan bahwa:

"Model Kemmis dan Mc. Taggart merupakan hasil dari pengembangan model yang sudah diciptakan oleh Kurt Lewin. Kemmis dan Mc. Taggart menjelaskan bahwa Acting (tindakan) dan Observing (pengamatan) dijadikan satu kesatuan, hal ini didasari bahwa pada kenyataan penerapan tindakan dan pengamatan tidak dapat dipisahkan karena kegiatan ini dilakukan dalam waktu bersamaan. Dalam model Kemmis dan Mc.Taggart terdapat empat komponen yang dipandang sebagai suatu siklus yaitu: perencanaan, tindakan, observasi dan refleksi. Dalam model ini banyaknya siklus tergantung pada permasalahan yang dipecahkan".

Pengumpulan data adalah prosedur yang tersistematik dan standar untuk memperoleh data yang diperlukan. Jenis data yang diperlukan dalam penelitian ini adalah data kualitatif dan kuantitatif yang terdiri dari data hasil belajar, rencana pembelajaran, hasil observasi terhadap pelaksanaan pembelajaran. Data-data ini bersumber dari peserta didik dan data penelitian dengan melihat variable dalam penelitian in, maka teknik pengumpulan data dilakukan dengan beberapa cara antara lain sebagai berikut:

Observasi adalah kegiatan untuk pengumpulan data yang dilakukan melalui pengamatan atas gejala fenomena dan fakta empiris terkait dalam masalah penelitian. Observasi dalam penelitian ini digunakan untuk pengumpulan data dan mengamati kegiatan peserta didik dan guru selama proses pembelajaran pada mata pelajaran IPS dengan mengunakan metode pembelajaran kooperatif tipe Student Team Achievement Division (STAD).

Tes adalah serangkaian pertanyaan atau latihan yang digunakan untuk mengukur pengetahuan, kemampuan atau bakat, 
inteligensia, keterampilan yang dimiliki individu atau kelompok (Hartono, 2011:38). Tujuan tes adalah untuk mendapatkan informasi tentang seberapa jauh peserta didik sudah menyerap isi bahan pelajaran yang disajikan oleh guru dalam kegiatan belajar mengajar.

Tes yang digunakan dalam penelitian ini ada dua yaitu sebagai berikut:

I) Tes Awal (Pre-Test)

Tes ini adalah tes yang akan dilaksanakan sebelum bahan pelajaran diberikan kepada peserta didik. Dimana tes awal ini bertujuan untuk mengetahui sejauh mana materi atau bahan pelajaran yang akan diajarkan dapat dikuasai oleh peserta didik.

\section{2) Tes Akhir (Post-Test)}

Tes yang dilaksanakan dengan tujuan untuk mengetahui kemampuan peserta didik setelah diberikan perlakuan tentang semua materi pelajaran yang tergolong penting sehingga dapat dikuasai dengan sebaik-baiknya oleh para peserta didik.

Menurut Sugiyono $(2010 ; 148)$ instrumen penelitian adalah suatu alat yang digunakan untuk mengukur fenomena alam atau suatu sosial yang diamati (variabel penelitian)". Jadi instrumen merupakan suatu alat yang digunakan oleh peneliti dalam proses untuk mengumpulkan data.

Teknik analisis data dalam penelitian ini menggunkan metode Mixed Methods atau metode kombinasi antara teknik analisis kualitatif dan teknik analisis kuantitatif, menurut Creswell, Jhon W (Diplan dan Andi, 2018:36) menyatakan bahwa:

"Penelitian mixed methods adalah pendekatan untuk menyelidiki kombinasi atau asosiasi antara bentuk kualitatif dan kuantitatif. Itu meliputi asumsi filosofi, menggunakan pendekatan kualitatif dan kuantitatif, dan menggabungkan kedua pendekatan dalam belajar. Itu mengumpulkan kedua pendekatan dua-duanya jadi lebih kuat dalam belajar adalah lebih besar daripada pendekatan kualitatif atau kuantitatif'.

Untuk melihat keberhasilan dari penelitian ini dengan indikator keberhasilan penelitian sebagai berikut:

Indikator keberhasilan dalam penelitian ini meliputi indikator proses yang ditandai oleh keaktifan peserta didik dalam proses pembelajaran sesuai dengan rencana pada tahap-tahap pembelajaran tercapai dengan model pembelajaran tipe Student Team Achievement Division (STAD).

Aktifitas belajar peserta didik dikatakan baik jika setiap peserta didik memperoleh skor dan secara klasikal jumlah peserta didik yang memiliki skor $\geq 72$ mencapai $85 \%$ dari jumlah seluruh peserta didik.

Berdasarkan standar nilai KKM yang telah ditentukan oleh pihak SMP Muhammadiyah Palangkaraya untuk mata pelajaran IPS, dimana seorang peserta didik dikatakan berhasil atau tuntas jika nilai yang diperoleh sesuai atau kriteria ketuntasan minimal yaitu 72 dan secara klasikal terdapat 85\% peserta didik yang memperoleh nilai $\geq$ 72.

Hasil belajar dikatakan meningkat jika rata-rata hasil tes akhir (post-test) lebih besar dari pada hasil tes awal (pre-test).

\section{HASIL PENELITIAN DAN PEMBAHASAN}

Pra tindakan adalah perlakuan awal pendidik kepada peserta didik memasuki materi yang di ajarkan. Dalam melakukan pra tindakan penddik harus melakukan observasi dan tes pra tindakan. Sehingga dapat dijadikan sebagai tolak ukur keberhasilan pembelajaran, selanjutnya kedua data tersebut di deskripsikan sebagai berikut.

Tes pra tindakan dalam penelitian ini yaitu bertujuan untuk mengetahui tingkat pemahaman peserta didik terhadap materi yang akan di jadikan topik pembelajaran sebelum penelitian tindakan kelas 
dilaksanakan. Tes yang dilakukan dalam penelitian ini dilaksanakan dengan memberikan pelajaran tanpa menggunakan metode pembelajaran tipe Student Team Achievement Division, kemudaian peserta didik mengerjakan soal berupa pilihan ganda yang berjumlah 20 (dua puluh) butir soal.

\section{Data Refleksi Siklus I}

Pada proses tindakan siklus I peneliti menerapkan metode kerja kelompok untuk meningkatkan hasil belajar IPS dari hasil refleksi serta diskusi kegiatan pembelajaran yang telah dilaksanakan berdasarkan hasil data lembar observasi yang diperoleh dua observer yaitu, adanya berbagai hambatan dan kekurangan yang terjadi pada siklus I. Guru memiliki beberapa hambatan dan kekurangan pada siklus I sebagai berikut:

a) peserta didik kurang memperhatikan penjelasan guru

b) peserta didik kurang bersosialisasi dengan sesama peserta didik lainnya.

c) peserta didik kurang aktif saat menjawab kuis.

Berdasarkan uraian diatas, maka bagi guru hambatan dan kekurangannya yang akan perlu diperbaiki pada tahap siklus II sebagai berikut:

a. Guru sebaiknya menunjuk salah satu anggota kelompok untuk berbicara dan mengungkapkan pendapatnya.

b. Guru sebaiknya menambah konsep atau ide yang belum terungkap.

c. 3) Guru sebaiknya memberikan kesempatan kepada peserta didik untuk bertanya mengenai materi yang kurang dimengerti.

Guru sebaiknya menyimpulkan materi yang telah dipelajari. Bagi peserta didik hambatan dan kekurangan yang akan perlu diperbaiki pada tahap pada siklus II sebagai berikut:

a) Peserta didik sebaiknya memperhatikan penjelasan guru. b) Peserta didik sebaiknya bersosialisali dengan sesama peserta didik lainnya.

c) Peserta didik sebaiknya aktif bertanya dalam proses pembelajaran.

d) Peserta didik sebaiknya berpikir kreatif dalam proses pembelajaran.

\section{Data Refleksi Siklus II}

Hasil observasi pada siklus II mendeskripsikan adanya peningk atan yang baik dalam proses kegiatan pembelajaran IPS dengan menerapkan metode kerja kelompok, dari hasil observasi diatas terdapat peningkatan hasil observasi siklus I dan siklus II. Dimana hasil pada siklus II hasil belajar peserta didik mengalami peningkatan dengan 23 orang peserta didik yang memperoleh nilai tuntas dalam mengikuti pembelajaran dari total 25 peserta didik. Ada 2 peserta didik yang memperoleh nilai dibawah kriteria ketuntasan minimal (KKM). Demikian penelitian ini dikatakan berhasil atau berhenti.

Dari hasil oservasi diatas maka terdapat peningkatan dari observasi siklus I ke siklus II sehingga dapat disimpulkan bahwa observasi siklus II dapat dikatakan baik dan peneliti telah bisa memperbaiki kekurangan atau hambatan pada observasi siklus I.

Adapun hal-hal tersebut adalah :

a) Guru sudah tegas menunjuk salah satu dari anggota kelompok untuk berbicara saat itu dan ditanggapi atau dibahas oleh kelompok lainnya.

b) Guru sudah menambahkan konsep atau ide yang belum terungkap.

c) 3) Guru sudah memberikan kesempatan kepada peserta didik untuk bertanya mengenai materi yang kurang dimengerti

d) 4) Guru sudah dapat menyimpulkan materi yang telah dipelajari. Ditinjau dari proses siklus II dan hasil data yang telah diperoleh maka dapat disimpulkan bahwa proses kegiatan pembelajaran IPS materi 
kehidupan pada masa hindu- buddha dengan menrapkan metode Student Team Achievement Division pada siklus II telah berhasil.

\section{Deskripsi data siklus I dan siklus II}

Untuk dapat menarik kesimpulan dari penelitian ini, maka peneliti membandingkan hasil yang diperoleh pada siklus I dengan hasil yang diperoleh pada siklus II.

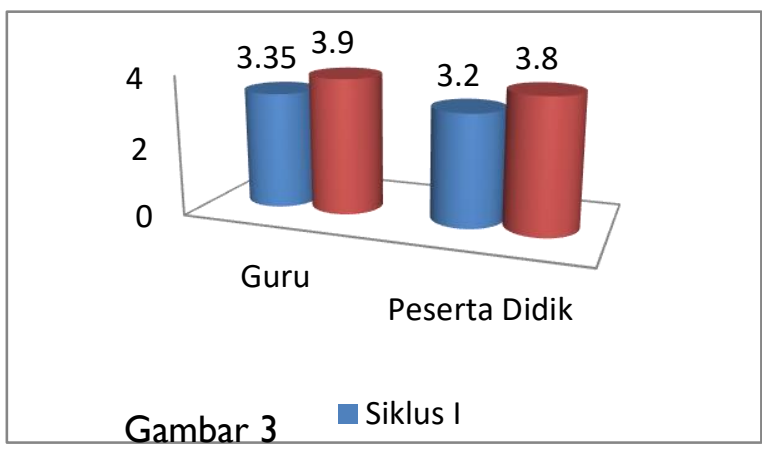

Grafik persentase aktivitas peserta didik dan aktivitas guru pada pembelajaran siklus I dan siklus II

Berdasarkan gambar grafik diatas diketahui bahwa aktifitas peserta didik dan aktivitas guru mengalami peningkatan setiap siklusnya.

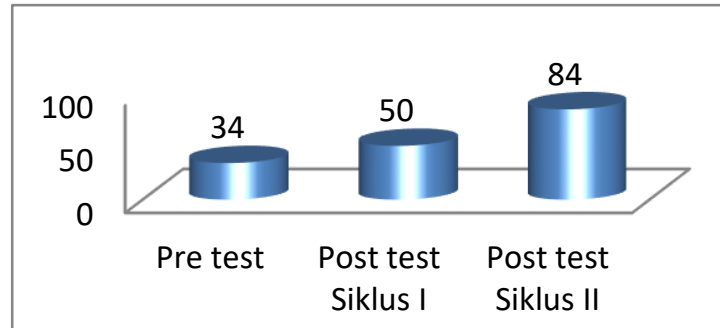

Gambar. 4匹 Skor Rata-rata

Grafik Persentase Hasil Belajar Peserta

Didik Pada Pre Test Dan Post Test siklus I dan siklus II

Berdasarkan tabel dan gambar grafik diatas maka dapat diketahui bahwa hasil belajar peserta didik mengalami peningkatan pada setiap siklusnya. Hal tersebut menunjukkan bahwa penggunaan model pembelajaran Student Team Achievement
Division dapat digunakan dan tepat untuk meningkatkan hasil belajar peserta didik.

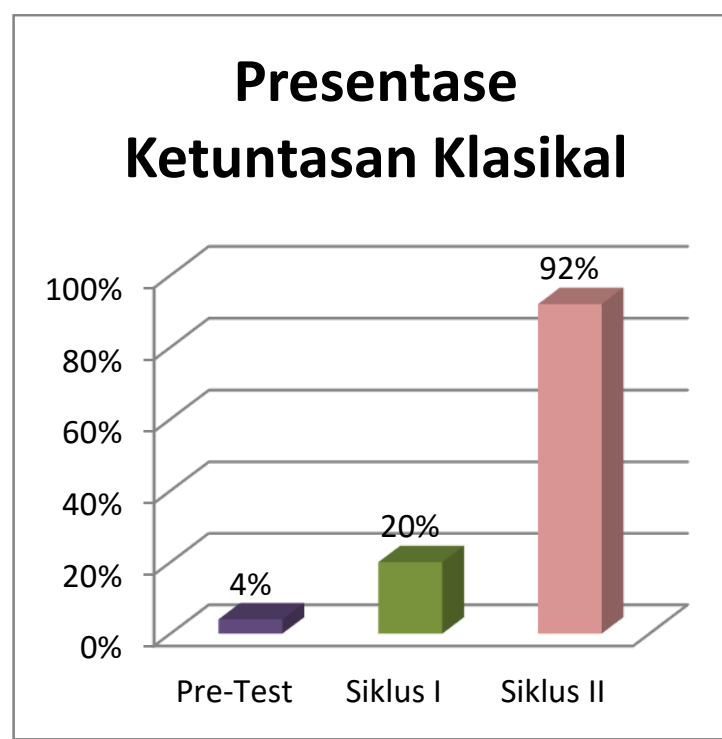

Gambar. 5

Grafik Presentase Ketuntasan Klasikal peserta didik

Berdasarkan gambar grafik diatas maka dapat diketahui bahwa hasil belajar klasikal peserta didik pada saat pre test sebesar 4,\% dengan nilai rata-rata 34 , sedangkan pada saat post test siklus I $20 \%$ dengan nilai rata-rata 50 adapun pada post test siklus II $92 \%$ engan nilai rata-rata 84 .

\section{KESIMPULAN}

Berdasarkan analisis data yang dilakukan terhadap aktivitas peserta didik maka dapat diperoleh hasil aktivitas peserta didik pada setiap siklusnya. Pada Siklus I, aktivitas peserta didik akif dalam mengikuti kegiatan pembelajaran dengan menggunakan model pembelajaran Tipe Student Team Achievement Division (STAD), namun ada beberapa peserta didik yang kurang berpartisipasi dalam memperhatikan temannya membacakan hasil diskusi kelompok. Pada Siklus II aktivitas peserta didik meningkat menjadi lebih aktif dalam mengikuti kegiatan pembelajaran dengan menggunakan model pembelajaran Tipe Student Team Achievement Division (STAD). 
Dikatakan lebih aktif karena tidak ada lagi peserta didik yang kurang berpartisipasi, peserta didik terlihat bersemangat ketika menjawab kuis yang diberikan guru dalam kelompoknya.

Penggunaan model pembelajaran Tipe Student Team Achievement Division (STAD) pada pembelajaran ekonomi melibatkan seluruh peserta didik secara aktif dalam proses pembelajaran, peserta didik terlibat dalam tugas kelompk yang dikerjakan oleh anggota-anggota kelompok. Hasil Belajar IPS Peserta Didik Pada Kelas Tipe Student Team Achievement Division (STAD) VII-C dengan Menggunakan Model Pembelajaran Tipe Student Team Achievement Division (STAD). Berdasarkan analisis data yang dilakukan terhadap hasil belajar peserta didik, maka dapat diperoleh hasil belajar peserta didik dari tes awal (pre test), post test Siklus I dan post test Siklus II. Pada saat tes awal (pre test), hasil belajar peserta didik memperoleh nilai ratarata 34 (dibawah nilai KKM $\geq 70$ ) dengan ketuntasan kalsikal $4 \%$ dengan kriteria kurang tercapai. Pada Siklus I hasil belajar peserta didik memperoleh nilai rata-rata 50 dengan ketuntasan klasikal $20 \%$ dengan kriteria kurang tercapai. Siklus II hasil belajar peserta didik memperoleh nilai rata-rata 84 dengan ketuntasan klasikal $92 \%$ dengan kriteria sangant tercapai.Hasil penelitian tersebut maka ada peningkatan hasil belajar IPS peserta didik dengan menggunakan model pembelajaran Tipe Student Team Achievement Division (STAD).

\section{DAFTAR PUSTAKA}

Aunurahman. 20I0. Belajar Dan Pembelajaran. Bandung: Pustaka Setia.

Diplan \& M. Andi, 2019. Metodologi penelitian Pendidikan. Jawa Tengah: Cv. Samu Untung.

Diplan dan Setiawan, Andi M. 2018. Penelitian Tindakan Kelas. Yogyakarta: Deepublish
Kunandar. 2012. Langkah Mudah Penelitian Tindakan Sebagai Pengembangan Profesi Guru. Jakarta: PT. Rja Grafindo Persada. Permadi, Ade Salahudin dan Muchlis Saini. 2017. Upaya Meningkatkan Hasil Belajar IPA melalui Penerapan Media Pembelajaran Berbasis Multimedia Peserta Didik. Bitnet: Jurnal Pendidikan Teknologi Informasi 2(2):20-26.

Putra, Chandra Anugrah dan Nikita Dewi. 2017. Upaya Meningkatkan Hasil Belajar IPS dengan Menggunakan Strategi Pembelajaran Inkuiri (SPI). Bitnet : Jurnal Pendidikan Teknologi Informasi 2(2):II19.

Septiana, Yulisa dan Muhammad Jailani. 2019. Upaya Meningkatkan Motivasi Belajar dan Hasil Belajar Ekonomi dengan Menggunakan Model Student Team Achievement Division (STAD) pada Kelas $X$ di SMA Negeri I Katingan Hilir. Neraca: Jurnal Pendidikan Ekonomi 4(2):33-40.

Setiawan, M Andi. 2017. Belajar dan Pembelajaran. Ponorogo: Uwais Inspirasi Indonesia.

Slavin, Robert, E. 2010. Cooperatif Larning. Bandung: Nusa Media.

Suprihatiningrum. 2014. Strategi Pembelajaran Teori dan Aplikasi, Yogyakarta: Pustaka Belajar. 